\title{
Increased risk of endemic mosquito-borne diseases in Canada due to climate change
}

\author{
A Ludwig ${ }^{1 *}$, H Zheng², L Vrbova ${ }^{3}$, MA Drebot ${ }^{4}$, M Iranpour ${ }^{4}$, LR Lindsay ${ }^{4}$
}

\begin{abstract}
There are currently over 80 species of mosquito endemic in Canada-although only a few of these carry pathogens that can cause disease in humans. West Nile virus, Eastern equine encephalitis virus and the California serogroup viruses (including the Jamestown Canyon and snowshoe hare viruses) are mosquito-borne viruses that have been found to cause human infections in North America, including in Canada. Over the last 20 years, the incidence of most of these endemic mosquito-borne diseases (MBD) has increased approximately $10 \%$ in Canada, due in large part to climate change. It is anticipated that both the mosquito lifecycle and virus transmission patterns will be affected by climate change, resulting in an increase in both the range and local abundance of several important mosquito species. Laboratory studies and mathematical modelling suggest that increased ambient temperatures, changes in precipitation and extreme weather events associated with climate change will likely continue to drive mosquito vector and MBD range expansion, increasing the duration of transmission seasons and leading to MBD-related epidemics. Furthermore, Canada's endemic MBDs have complex transmission cycles, involving multiple reservoir hosts (birds and mammals), multiple pathogens and multiple mosquito species-all of which may be sensitive to climate and other environmental changes, and making forecasting of potential emerging trends difficult. These expected climate-induced changes in mosquitoes and MBDs underline the need for continued (and expanded) surveillance and research to ensure timely and accurate evaluation of the risks to the public health of Canadians.
\end{abstract}

Suggested citation: Ludwig A, Zheng H, Vrbova L, Drebot MA, Iranpour M, Lindsay LR. Increased risk of endemic mosquito-borne diseases in Canada due to climate change. Can Commun Dis Rep 2019;45(4):90-7.

https://doi.org/10.14745/ccdr.v45i04a03

Keywords: mosquito-borne disease, West Nile virus, Eastern equine encephalitis, California serogroup virus, endemic, Canada, climate change
This work is licensed under a Creative Commons Attribution 4.0 International License.

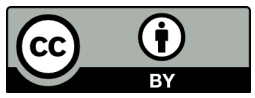

Affiliations

${ }^{1}$ National Microbiology Laboratory, Public Health Agency of Canada, St. Hyacinthe, QC

${ }^{2}$ Center for Food-borne, Environmental and Zoonotic Infectious Diseases, Public Health Agency of Canada, Ottawa, ON

${ }^{3}$ Center for Food-borne and Environmental \& Zoonotic Infectious Diseases, Public Health Agency of Canada, Toronto, ON

${ }^{4}$ National Microbiology Laboratory, Public Health Agency of Canada, Winnipeg, MN

*Correspondence: antoinette. ludwig@canada.ca

\section{Introduction}

The United Nations' Intergovernmental Panel on Climate Change report identified mosquito-borne diseases (MBDs) as the infectious diseases that are most sensitive to climate change (1). Canada has already experienced climate changes, and the observed trends have included warming, increased occurrence of extreme heat and heavy rainfall events, and decreased number of frost days (2). These changes are expected to intensify in the coming decades until greenhouse gas emissions start to decrease globally.

These climate changes are expected to influence Canada's flora and fauna in anticipated and unanticipated ways. Included in the fauna that are expected to be affected by climate change are the diverse and plentiful mosquito populations. In addition to being seen as a nuisance due to their bites, a few species can also transmit infectious disease organisms.

This paper focuses on the mosquitoes that are endemic to Canada, and the diseases that they can carry, which are referred to as endemic mosquito-borne diseases. These are distinct from the foreign MBDs that can be acquired outside Canada, although these may emerge in Canada in the future (3). The most medically-important endemic MBD in Canada is West Nile virus (WNV) infection. Other endemic MBDs include Eastern equine encephalitis virus (EEEV) and two California serogroup viruses (CSGV): Jamestown Canyon virus and snowshoe hare virus (4-8). All of these endemic MBDs are transmitted by endemic arboviruses (an acronym for ARthropod-BOrne virus, referring to any virus transmitted by an arthropod vector). Arthropods include mosquitoes, ticks and blackflies; the focus of this paper is specifically on mosquitoes. Arthropod vectors are cold-blooded, so they are especially sensitive to climatic factors.

The objective of this study is to provide an overview of mosquitoes in Canada, summarize how climate change may increase the risk of endemic MBDs, discuss what endemic MBDs are likely to increase both in urban and rural settings and identify what can be done to address these risks. 


\section{Endemic mosquito species in Canada}

All four of the important endemic to Canada arboviruses (WNV, EEEV, Jamestown Canyon virus and snowshoe hare virus) are transmitted through bites of infected female mosquitoes that have acquired pathogens from specific mammalian or avian reservoir hosts (9). The main mosquito vectors for WNV are Culex pipiens and Cx. restuans in eastern Canada and $C x$. tarsalis in western Canada (10). The main vector for EEEV is Culiseta melanura $(11,12)$ and the main vectors for CSGV are a variety of non-Culex mosquitoes species (e.g. Aedes, Culiseta and Anopheles species) (13-15). Included in the CSGV are Jamestown Canyon and snowshoe hare viruses. The reservoirs for these pathogens vary between the mosquito species; for example, the main animal reservoir of Jamestown Canyon virus is the white-tailed deer (16), while for snowshoe hare virus it is (not surprisingly) the snowshoe hare and other small mammals (8). Humans are incidental or "dead-end" hosts for the endemic arboviruses; meaning that although they can be infected, they cannot subsequently transmit viruses to feeding mosquitoes with any efficiency due to low and transient viremia $(4,10)$. Arboviruses can also occasionally be transmitted by blood transfusion or tissue transplants $(17,18)$.

In addition to these traditionally endemic mosquitoes, many additional species have been introduced into Canada over the past few decades. In the 1970s, a comprehensive review of the insects and arachnids of Canada reported that there were 74 mosquito species (19). In the intervening 40 years, six species have been reported as newly established in Canada: Ochlerotatus ventrovittis; Oc. japonicus; Cx. salinarius; Cx. erraticus; An. perplexens; and An. crucians [(20), and M Iranpour unpublished data]. In addition, the geographic range of 10 species has expanded in Canada: Uranotaenia sapphirina; Cs. melanura; Cs. minnesotae; Cx. tarsalis; Oc. sticticus; Oc. spencerii; Oc. dorsalis; Oc. nigromaculis; Oc. campestris; and Oc. cataphylla (21). So there are now approximately 80 mosquito species in Canada.

Recently, invasive Aedes species have been found in southern Ontario and southern Quebec. Small numbers of Aedes albopictus were detected in parts of Windsor-Essex County in southern Ontario in 2016, 2017 and 2018 (22). The repeated detection of this species, over a number of collections sites, suggests that this species is now becoming endemic in this part of Canada. Specimens of Ae. aegypti were also collected at some of the same sites in Windsor, Ontario in 2016 and 2017 and at a single site in southern Quebec in 2017. Although these two Aedes strains are well known for transmission of exotic (non-native to Canada) MBD (3), they can also be a vector for MBDs already endemic to Canada, including WNV.

\section{Climate change will increase the risk of endemic mosquito-borne diseases}

The key aspects of climate change that affect endemic mosquitoes are increases in temperature, and changes in rainfall patterns. An increase in precipitation generally increases the potential egg-laying and larval habitat for mosquitoes in the environment. The relationship is often non-linear, with above average rainfall generally increasing the abundance of mosquitoes by increasing the availability of standing water, while excessive or violent precipitation can play a leaching role and destroy the eggs and flush larvae from selected habitats (23). Elevated temperatures can increase rates of development of immature stages of the mosquito lifecycle, leading to higher reproductive rates and exponential population increases $(24,25)$. These elevated temperatures shorten the extrinsic incubation period, so mosquitoes that have acquired infection become infectious sooner; for example, outbreaks of WNV infection appear to occur more frequently in Canada when seasonal temperatures are above average, as these conditions promote rapid build-up of virus in vector mosquitoes and favour extended host-seeking by potentially infected female mosquitoes (26). It has been reported that in Korea and Japan, the duration of the transmission season can be extended by several months when average summer temperatures increase by as little as $5^{\circ} \mathrm{C}$ (27). Changes in rainfall affect the availability of standing water, which is where mosquitoes lay their eggs and where immature mosquitoes live. Consequently, changes in rainfall strongly affect mosquito reproduction $(28,29)$.

The impact of climate change on WNV transmission in Canada has been investigated in two studies with similar conclusions $(30,31)$. Chen and colleagues $(30)$ examined WNV transmission in the Prairies (where Cx. tarsalis is the main vector) and have projected an extension of seasonal activity of WNV-infected $C x$. tarsalis from three months (June to August) to five months (May to September) by the 2080s. These authors also predicted a northward range expansion for $C x$. tarsalis and WNV. Hongoh et al. (31) modelled the potential distribution of Cx. pipiens populations in eastern Canada and predicted a similar northward range expansion for this eastern vector of WNV.

Birds and some mammals are important reservoirs for WNV and other MBDs. For WNV, a wide range of bird species serve as reservoirs, including corvids (i.e. crows, jays and magpies) and passerines (i.e. robins, sparrows, finches and starlings) (10,32-34). For other MBDs, mammals, such as deer, squirrels, chipmunks and hares, are the reservoir hosts. Climate change could affect these reservoir host populations in several ways, influencing their abundance and species distributions. It is possible that climate change could also affect individual and population health of the reservoir hosts as the more abundant viruses could also harm them directly. 
It is important to note that proliferation of mosquitoes and MBDs can also be affected by other environmental changes, including land-use changes, as well as vector control activities $(35,36)$. Habitat loss and fragmentation (37) can also impact avian and mammal reservoirs (38).

\section{Current and emerging endemic mosquito-borne diseases}

Different mosquito species have different characteristics with respect to preferred habitats and pathogen load. With climate change, WNV may increase in both urban and rural areas whereas other MBDs, such as EEEV and CSGV, may increase, particularly in rural areas. The following provides a short description of the current and emerging endemic MBDs.

\section{West Nile virus may increase in both rural and urban areas}

West Nile virus is transmitted by $C x$. pipiens, which is largely an urban mosquito, and Cx. tarsalis, which is largely a rural mosquito. Effects of climate change may affect WNV risk, particularly in urban areas in the east, and rural areas in the Prairies. The increase of number of mosquitoes, including those infected with MBDs, will have a more significant impact on public health in urban areas because that is where the vast majority of Canadian resides. Early symptoms of WNV include fever, headache, skin rash, nausea and muscle aches. Most affected people recover fully, but approximately $1 \%$ develops severe illness (meningitis, encephalitis, acute flaccid paralysis and poliomyelitis). Those over 70 years of age with underlying medical conditions and those who are immunocompromised are at greater risk of severe illness (39-42).

Since 2002, the annual reported incidence of WNV human cases has fluctuated significantly, ranging from 1,481 in 2003 to five cases in 2010 and 2,215 cases in 2007, which may be due in part to variations in weather affecting mosquito reproduction and virus transmission and variation in reporting (43). Geographical variation in the number of reported human cases of WNV has been dramatic as well: in 2003 and 2007 most human cases of WNV were reported from the Prairie regions (Alberta, Saskatchewan and Manitoba), but in 2002, 2012 and 2018 most cases occurred in Ontario and Quebec (43). This geographic variation is likely associated with local effects of weather on the different vectors, and on virus transmission and again, to some variation in reporting $(28,29,44)$.

\section{Eastern equine encephalitis and California serogroup viruses will increase in rural areas}

Eastern equine encephalitis virus is transmitted by $C$. melanura mosquitoes, which thrive in freshwater swamps $(11,12)$. The reservoir for this virus is avian hosts. Eastern equine encephalitis infection can be asymptomatic, or present as one of two types of illness: systemic or encephalitic. Approximately a third of all people with encephalitis will die from the disease (45). A single human EEEV case was reported in Ontario in 2016 (43). Eastern equine encephalitis has been responsible for sporadic outbreaks in horses (and exotic birds) in Ontario since 1939 (46). Atypically large outbreaks of EEEV in horses were reported in Ontario, Quebec and Nova Scotia in 2008, 2009 and 2010 (46).

California serogroup viruses are transmitted via a number of mosquito species. The CSGV can cause febrile illness and neurologic disease (47). New testing methods were introduced in 2005 and over 200 probable and confirmed cases of CSGV were reported to the Public Health Agency of Canada and/or provincial public health laboratories from 2005 to 2014 (M Drebot unpublished data). Cases have been identified in all provinces as well as in the Northwest Territories and other northern regions. As well, seroprevalence studies have identified rates of exposure as high as $20 \%-40 \%$ or greater in specific regions of Canada [(48-50), and M Drebot unpublished data]. Since 2015, between 20 and 40 human cases have been observed annually in Canada, with the exception of 2017, when 122 cases were reported (43). This dramatic increase may be due, at least in part, to enhanced testing of those who presented with a WNV-like illness (patients were negative when tested for WNV, so further testing was requested). Based on the National WNV and other Arbovirus Report, there were more than 100 cases of Jamestown Canyon and snowshoe hare viruses in Quebec in 2017 (H Zheng, $H$ Wood and M Drebot, National WNV and other Arbovirus Report, unpublished report). It is quite likely that CSGV cases are under-diagnosed due to the low level awareness of these pathogens among physicians and other health care practitioners.

\section{Current clinical and public health response}

In the absence of vaccines or specific treatments, reducing mosquito habitat, reducing mosquito bites, early and accurate testing for MBDs in humans and ongoing surveillance form the core of the clinical and public health response.

\section{Preventive measures: preventing mosquito bites prevents infection}

There is no vaccine or specific treatment for WNV, EEEV or CSGV infections, so prevention of infective mosquito bites is the cornerstone of control (43). Bites can be reduce by covering the skin (e.g. wearing long pants and loose-fitting shirts with long sleeves) and/or by using insect repellent containing the chemicals N,N-diethyl-3-methylbenzamide (DEET) or icaridin (51). Reducing mosquito habitat near homes, mainly by removing standing water, is also important. Municipalities, often in collaboration with provincial governments, have also funded mosquito abatement programs designed to reduce the size of nuisance and vector mosquito populations. The scope of these programs is highly variable across Canada but typically involve source reduction 
(removal of standing water), application of larvicides to standing water and, less frequently, aerial or vegetative treatments with products designed to kill adult mosquitoes.

\section{Early diagnosis and testing of arboviruses}

Early detection of MBDs is important to avoid potentially severe complications. Diagnosis of arbovirus infections can be challenging as patients often initially present with non-specific symptoms. The diagnosis of MBDs must be confirmed with laboratory testing. The National Microbiology Laboratory (Winnipeg) is the reference lab for EEEV and CSGV testing and for WNV for the provinces with low WNV occurrences (i.e. Newfoundland and Labrador, Prince Edward Island, Nova Scotia and New Brunswick). The provinces with higher WNV occurrences do their own testing.

\section{Surveillance}

The World Health Organization has highlighted the importance of identifying and monitoring various vector populations as a component of global surveillance, including mosquitoes that may carry and transmit arboviruses, as surveillance for risk in mosquito populations is more timely than waiting for human disease cases to appear (52).

Currently, surveillance for arboviruses varies somewhat across jurisdictions in Canada and much of the effort has focused in the Prairies, Ontario and Quebec, where disease incidence is typically highest. For WNV, mosquito surveillance involves the counting of the different species of mosquitoes and calculating the infectivity rate in species that carry WNV. This surveillance approach needs to be expanded in terms of the geographical areas and the MBDs that are monitored. By doing this, changing boundaries of WNV can be tracked and the emergence of mosquitoes infected with EEEV, Jamestown Canyon virus, snowshoe hare virus and more can be detected to inform public health action.

Since WNV is currently a notifiable disease in Canada, surveillance includes monitoring the incidence of human infections, including detection the presence of WNV in blood donations (all donations are tested for a wide range of diseases and pathogens). In addition, mortality and morbidity trends in wild bird populations and in horses and other domesticated animals are monitored. These data are collected by provinces and territories for action by these jurisdictions, but surveillance information is also transferred to, synthesized and analyzed by the Public Health Agency of Canada, to provide a national picture that is disseminated to provincial and territorial partners on a weekly basis (43).

Since EEEV, Jamestown Canyon and snowshoe hare virus infections are not currently nationally notifiable diseases in Canada, there are no national surveillance programs to monitor their activity in mosquitoes, reservoirs or human populations. Nevertheless, the National Microbiology Laboratory tested for these arboviruses in patients who presented with symptoms consistent with arboviral infections; identifying cases of both Jamestown Canyon and snowshoe hare virus infections $(8,43)$. The National Microbiology Laboratory has also carried out seroprevalence studies for other orthobunyaviruses, such as Cache Valley virus. Cache Valley virus can cause neurological disease in both humans and livestock (53) and cases of symptomatic illness have been associated with positive serology in patients from Manitoba, Saskatchewan and Alberta (M Drebot unpublished data).

\section{Discussion}

Climate change will undoubtedly influence the extent to which viruses are spread by endemic mosquitoes in the future, with increases in numbers and populations of endemic species (including those associated with arboviruses) and with introduction of new species (and associated pathogens) into Canada. Predicting how MBDs will respond to changes in climate is challenging: mosquitoes, reservoirs and the environment differ in their dependencies on climate change $(54,55)$. This means that even modest climate changes may drive large increases in arbovirus transmission $(1,56)$.

In addition, each MBD has unique transmission cycles, reservoirs and vectors. These may exist only in selected regions of Canada, so changes in prevalence of MBDs will be different from one region/landscape/habitat to another. It is anticipated that WNV will increase in both the rural and urban areas and the other currently endemic arboviruses (i.e. EEEV and CSGV) will increase in the rural areas.

There is a need to further explore the possible impacts of climate change on WNV, EEEV and CSGV in Canada. Ideally, these studies should consider and model each transmission cycle as a whole, not focusing only on one aspect, such as mosquito density or reservoir population dynamics. It will be important to advance our surveillance capacity not only for the expansion of existing arboviruses into new geographical areas but also for the appearance of new arboviruses, and to conduct research studies to better understand the changing and potentially expanding dynamics of arbovirus transmission dynamics.

The portrait of endemic mosquito species in Canada is always changing, and these changes in mosquito species (type, distribution and activity) are exacerbated by changes in our climate; clinicians and public health professionals will need to be aware of how these changes may impact MBD across Canada. We expect that the mean number of cases will increase, in conjunction with an increase in the number of different types of endemic arboviruses, in a relatively sporadic and unpredictable way. This will require a heightened vigilance from front line public health professionals as well as testing/surveillance laboratories. 


\section{Conclusion}

Climate change is anticipated to have significant effects on Canada's endemic mosquito populations and thus on MBDs such as WNV, EEEV and CSGV. MBDs have complex transmission cycles, involving multiple reservoir hosts (birds and mammals), and sometimes multiple mosquito species-all of which may all be differentially sensitive to climate and other environmental changes. Since WNV is a reportable disease, some data exists on disease prevalence and how this has changed over time, but much less is known about EEEV and CSGV. Reporting, and adequate treatment, is complicated by the symptoms of the MBDs, which may be less than definitive. The sporadic appearance of some MBDs has hampered the implementation of diagnostic testing for selected arboviruses at the provincial level and centralization of testing (at the National Microbiology Laboratory) is more cost effective for some arboviruses.

The expected climate-induced changes in mosquitoes and MBDs underline the need for continued surveillance and research to ensure timely and accurate evaluation of the public health risks to Canadians. Public health professionals and clinicians need to promote awareness among Canadians of this important public health risk and be vigilant for the emergence and spread of new strains of mosquitoes and new mosquito-borne diseases.

\section{Authors' statement}
$\mathrm{AL}$ - Principal writer
$\mathrm{HZ}$ - Co-writer and reviewed drafts
LV - Co-writer and reviewed drafts
MAD - Co-writer and reviewed drafts
LRL - Co-writer and reviewed drafts
$\mathrm{Ml}$ - Co-writer and reviewed drafts

\section{Conflict of interest}

None.

\section{Funding}

This work was supported by the Public Health Agency of Canada.

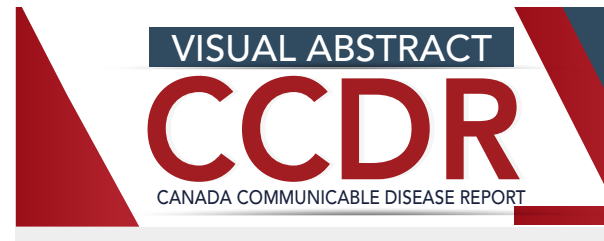

\section{CLIMATE CHANGE AND THE INCREASED RISK OF ENDEMIC MOSQUITO-BORNE DISEASES (MBDs)}

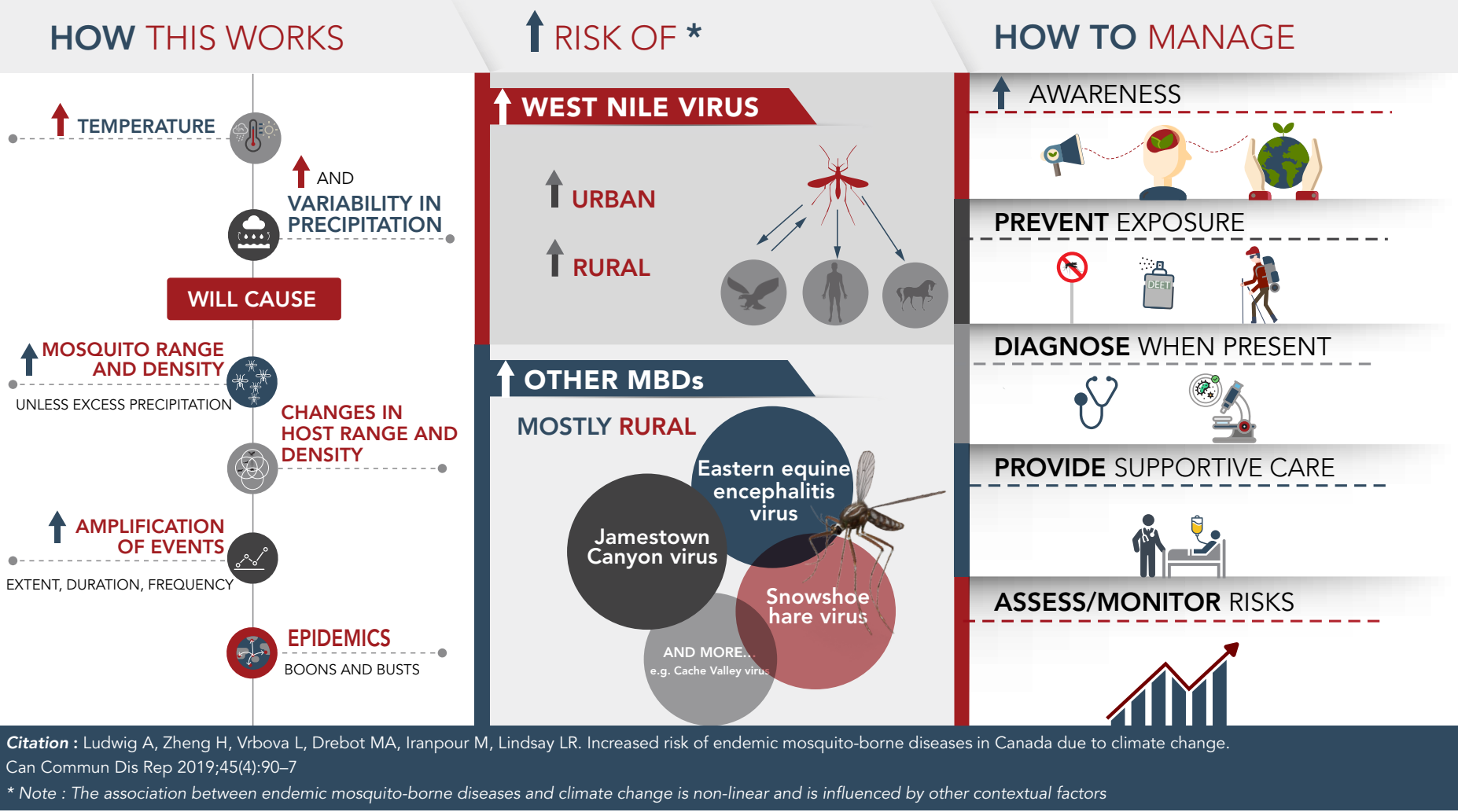




\section{References}

1. Smith KR, Woodward A, Campbell-Lendrum D, Chadee DD, Honda Y, Liu Q, Olwoch JM, Revich B, Sauerborn R. Climate Change 2014: Impacts, Adaptation, and Vulnerability. Part A: Global and Sectoral Aspects. Contribution of Working Group II to the Fifth Assessment Report of the Intergovernmental Panel on Climate Change (WG11AR5). Cambridge (UK) and New York (NY): Cambridge University Press; 2014. Chapter 11, Human health: impacts, adaptation, and co-benefits; pp. 709-54. www.ipcc.ch/site/assets/uploads/2018/02/WGIIAR5Chap11_FINAL.pdf

2. Romero-Lankao P, Smith JB, Davidson DJ, Diffenbaugh NS, Kinney PL, Kirshen P, Kovacs P, Villers Ruiz L. Climate Change 2014: Impacts, Adaptation, and Vulnerability. Part B: Regional Aspects. Contribution of Working Group II to the Fifth Assessment Report of the Intergovernmental Panel on Climate Change (WG11AR5). Cambridge (UK) and New York (NY): Cambridge University Press; 2014. Chapter 26, North America; pp. 1439-98. https://www.ipcc.ch/report/ar5/wg2/

3. $\mathrm{Ng} \mathrm{V}$, Rees EE, Lindsay LR, Drebot MA, Brownstone T, Sadeghieh T, Khan SU. Could exotic mosquito-borne diseases emerge in Canada with climate change? Can Commun Dis Rep 2019;45(4):98-107.

4. Kulkarni MA, Berrang-Ford L, Buck PA, Drebot MA, Lindsay $\mathrm{LR}$, Ogden NH. Major emerging vector-borne zoonotic diseases of public health importance in Canada. Emerg Microbes Infect 2015 Jun;4(6):e33. PubMed

5. Rocheleau JP, Michel P, Lindsay LR, Drebot M, Dibernardo A, Ogden NH, Fortin A, Arsenault J. Risk factors associated with seropositivity to California serogroup viruses in humans and pet dogs, Quebec, Canada. Epidemiol Infect 2018 Jul;146(9):1167-76. DOl PubMed

6. Zheng H, Drebot MA, Coulthart MB. West Nile virus in Canada: ever-changing, but here to stay. Can Commun Dis Rep 2014 May;40(10):173-7. DOI PubMed

7. Patriquin G, Drebot M, Cole T, Lindsay R, Schleihauf E, Johnston BL, Dimitrova K, Traykova-Andonova M, Mask A, Haldane D, Hatchette TF High seroprevalence of Jamestown Canyon virus among deer and humans, Nova Scotia, Canada. Emerg Infect Dis 2018 Jan;24(1):118-21. DOI PubMed

8. Drebot MA. Emerging mosquito-borne bunyaviruses in Canada. Can Commun Dis Rep 2015 Jun;41(6):117-23. DOI PubMed

9. Grubaugh ND, Ebel GD. Dynamics of West Nile virus evolution in mosquito vectors. Curr Opin Virol 2016 Dec;21:132-8. DOl PubMed

10. Kramer LD, Styer LM, Ebel GD. A global perspective on the epidemiology of West Nile virus. Annu Rev Entomol 2008;53:61-81. DOI PubMed

11. Armstrong PM, Andreadis TG. Eastern equine encephalitis virus in mosquitoes and their role as bridge vectors. Emerg Infect Dis 2010 Dec;16(12):1869-74. DOl PubMed

12. Molaei G, Andreadis TG, Armstrong PM, Anderson JF, Vossbrinck CR. Host feeding patterns of Culex mosquitoes and West Nile virus transmission, northeastern United States. Emerg Infect Dis 2006 Mar;12(3):468-74. DOI PubMed

13. LeDuc JW. Epidemiology and ecology of the California serogroup viruses. Am J Trop Med Hyg 1987 Nov;37(3 Suppl):60S-8S. DOI PubMed

14. Pastula DM, Hoang Johnson DK, White JL, Dupuis AP 2nd, Fischer M, Staples JE. Jamestown Canyon Virus Disease in the United States-2000-2013. Am J Trop Med Hyg 2015 Aug;93(2):384-9. DOI PubMed

15. Webster D, Dimitrova K, Holloway K, Makowski K, Safronetz D, Drebot MA. California Serogroup Virus Infection Associated with Encephalitis and Cognitive Decline, Canada, 2015. Emerg Infect Dis 2017 Aug;23(8):1423-4. DOl PubMed

16. Andreadis TG, Anderson JF, Armstrong PM, Main AJ. Isolations of Jamestown Canyon virus (Bunyaviridae: Orthobunyavirus) from field-collected mosquitoes (Diptera: Culicidae) in Connecticut, USA: a ten-year analysis, 19972006. Vector Borne Zoonotic Dis 2008 Apr;8(2):175-88. DOI PubMed

17. Public Health Agency of Canada Pathogen Safety Data Sheets: Infectious Substances - West Nile virus (WNV). Ottawa (ON): PHAC;2018. https://www.canada.ca/en/publichealth/services/laboratory-biosafety-biosecurity/pathogensafety-data-sheets-risk-assessment/west-nile-virus.html

18. Fonseca K, Prince GD, Bratvold J, Fox JD, Pybus M, Preksaitis JK, Tilley P. West Nile virus infection and conjunctival exposure. Emerg Infect Dis 2005 Oct;11(10):1648-9. DOI PubMed

19. Wood DM, Dang PT, Ellis RA. The Insects and Arachnids of Canada. Part 6: The Mosquitoes of Canada Diptera: Culicidae. Publication 1686. Ottawa (ON): Biosystematics Research Institute, Research Branch, Agriculture Canada; 2012. https://issuu.com/agropec/docs/insects_and_ arachnids_part_6

20. Giordano BV, Gasparotto A, Hunter FF. A checklist of the 67 mosquito species of Ontario, Canada. J Am Mosq Control Assoc 2015 Mar;31(1):101-3. DOl PubMed

21. Iranpour M, Lindsay LR, Dibernardo A. Culiseta melanura (Diptera: Culicidae), a new record for the Manitoba mosquito fauna. Proc Entomol Soc Manitoba. 2009;5:21-5. https:// home.cc.umanitoba.ca/ fieldspg/pdf/Iranpour_et_al_2009. pdf

22. June CB. 5, 2018. www.cbc.ca/news/canada/windsor/ mosquito-trap-captures-known-carriers-zika-virus-1.4693081

23. Clements AN. The Biology of Mosquitoes, Vol 1 Development, Nutrition and Reproduction. CABI Publishing; 1992. 532 p. www.cabi.org/bookshop/book/9780851993744

24. Alto BW, Juliano SA. Temperature effects on the dynamics of Aedes albopictus (Diptera: Culicidae) populations in the laboratory. J Med Entomol 2001 Jul;38(4):548-56.DOI PubMed 
25. Semenza JC, Suk JE, Estevez V, Ebi KL, Lindgren E. Mapping climate change vulnerabilities to infectious diseases in Europe. Environ Health Perspect 2012 Mar;120(3):385-92. DOI PubMed

26. Mallya S, Sander B, Roy-Gagnon MH, Taljaard M, Jolly A, Kulkarni MA. Factors associated with human West Nile virus infection in Ontario: a generalized linear mixed modelling approach. BMC Infect Dis 2018 Mar;18(1):141. DOI PubMed

27. Lee SH, Nam KW, Jeong JY, Yoo SJ, Koh YS, Lee S, Heo ST, Seong SY, Lee KH. The effects of climate change and globalization on mosquito vectors: evidence from Jeju Island, South Korea on the potential for Asian tiger mosquito (Aedes albopictus) influxes and survival from Vietnam rather than Japan. PLoS One 2013 Jul;8(7):e68512.DOI PubMed

28. Wang J, Ogden NH, Zhu H. The impact of weather conditions on Culex pipiens and Culex restuans (Diptera: Culicidae) abundance: a case study in Peel Region. J Med Entomol 2011 Mar;48(2):468-75. DOI

29. Yoo EH, Chen D, Diao C, Russell C. The Effects of Weather and Environmental Factors on West Nile Virus Mosquito Abundance in Greater Toronto Area. Earth Interact 2016;20(3):1-22. DOI

30. Chen CC, Jenkins E, Epp T, Waldner C, Curry PS, Soos C. Climate change and West Nile virus in a highly endemic region of North America. Int J Environ Res Public Health 2013 Jul;10(7):3052-71. DOI PubMed

31. Hongoh V, Berrang-Ford L, Scott ME, Lindsay LR. Expanding geographical distribution of the mosquito, Culex pipiens, in Canada under climate change. Appl Geogr 2012;33(1):5362. DOI

32. Reisen WK. Ecology of West Nile virus in North America. Viruses 2013 Sep;5(9):2079-105. DOI PubMed

33. Ludwig A, Bigras-Poulin M, Michel P, Bélanger D. Risk factors associated with West Nile virus mortality in American Crow populations in Southern Quebec. J Wildl Dis 2010 Jan;46(1):195-208. DOI

34. Kilpatrick AM, Kramer LD, Jones MJ, Marra PP, Daszak P. West Nile virus epidemics in North America are driven by shifts in mosquito feeding behavior. PLoS Biol 2006 Apr;4(4):e82. DOI PubMed

35. Lafferty KD. The ecology of climate change and infectious diseases. Ecology 2009 Apr;90(4):888-900. DOI PubMed

36. Wilson K. Climate change and the spread of infectious ideas. Ecology 2009 Apr;90(4):901-2. DOI PubMed

37. Natural Resources Canada. Canada in a Changing Climate: Sector Perspectives on Impacts and Adaptation. Warren FJ, Lemmen DS, editors. Ottawa (ON):Government of Canada; 2014. 286 p. www.nrcan.gc.ca/environment/ resources/publications/impacts-adaptation/reports/ assessments/2014/16309
38. Berteaux D, Stenseth NC. Measuring, understanding and projecting the effects of large-scale climatic variability on mammals. Clim Res 2006;32(2):95-7.

39. Petersen LR, Carson PJ, Biggerstaff BJ, Custer B, Borchardt SM, Busch MP. Estimated cumulative incidence of West Nile virus infection in US adults, 1999-2010. Epidemiol Infect 2013 Mar;141(3):591-5. DOI PubMed

40. Petersen LR, Brault AC, Nasci RS. West Nile virus: review of the literature. JAMA 2013 Jul;310(3):308-15. DOI PubMed

41. Sejvar JJ. Clinical manifestations and outcomes of West Nile virus infection. Viruses 2014 Feb;6(2):606-23. DOI PubMed

42. Badawi A, Velummailum R, Ryoo SG, Senthinathan A, Yaghoubi S, Vasileva D, Ostermeier E, Plishka M, Soosaipillai $M$, Arora P. Prevalence of chronic comorbidities in dengue fever and West Nile virus: A systematic review and meta-analysis. PLoS One 2018 Jul;13(7):e0200200. DOI PubMed

43. Public Health Agency of Canada. Surveillance of West Nile virus. Ottawa (ON): PHAC; 2018 www.canada.ca/en/publichealth/services/diseases/west-nile-virus/surveillance-westnile-virus.html

44. Ripoche M, Campagna C, Ludwig A, Ogden NH, Leighton PA. Short-term Forecasting of Daily Abundance of West Nile Virus Vectors Culex pipiens-restuans (Diptera: Culicidae) and Aedes vexans Based on Weather Conditions in Southern Québec (Canada). J Med Entomol 2019 Feb; DOI PubMed

45. Centers for Disease Control and Prevention. Eastern Equine Encephalitis. Symptoms and Treatment. www.cdc.gov/ easternequineencephalitis/tech/symptoms.html

46. Chénier S, Côté G, Vanderstock J, Macieira S, Laperle A, Hélie P. An eastern equine encephalomyelitis (EEE) outbreak in Quebec in the fall of 2008. Can Vet J 2010 Sep;51(9):1011-5. PubMed

47. Webster D, Dimitrova K, Holloway K, Makowski K, Safronetz $D$, Drebot MA. California serogroup virus infection associated with encephalitis and cognitive decline, Canada, 2015. Emerg Infect Dis 2017 Aug;23(8):1423-4. DOI PubMed

48. Patriquin $G$, Drebot $M$, Cole $T$, Lindsay $R$, Schleihauf $E$, Johnston BL, Dimitrova K, Traykova-Andonova M, Mask A, Haldane D, Hatchette TF. High Seroprevalence of Jamestown Canyon Virus among Deer and Humans, Nova Scotia, Canada. Emerg Infect Dis 2018 Jan;24(1):118-21. DOI PubMed

49. Rocheleau JP, Michel P, Lindsay LR, Drebot M, Dibernardo A, Ogden NH, Fortin A, Arsenault J. Emerging arboviruses in Quebec, Canada: assessing public health risk by serology in humans, horses and pet dogs. Epidemiol Infect 2017 Oct;145(14):2940-8. DOI PubMed 
50. Sampasa-Kanyinga $H$, Lévesque $B$, Anassour-Laouan-Sidi E, Côté S, Serhir B, Ward BJ, Libman MD, Drebot MA, Makowski K, Dimitrova K, Ndao M, Dewailly E. Zoonotic infections in communities of the James Bay Cree territory: an overview of seroprevalence. Can J Infect Dis Med Microbiol 2013;24(2):79-84. DOI PubMed

51. Public Health Agency of Canada. Prevention of West Nile virus. Ottawa (ON): PHAC; 2016. www.canada.ca/en/publichealth/services/diseases/west-nile-virus/prevention-west-nilevirus.html

52. World Health Organization. A global brief on vector-borne diseases. Geneva (CH): WHO; 2014. www.who.int/ campaigns/world-health-day/2014/global-brief/en/
53. Uehlinger FD, Wilkins W, Godson DL, Drebot MA. Seroprevalence of Cache Valley virus and related viruses in sheep and other livestock from Saskatchewan, Canada. Can Vet J 2018 Apr;59(4):413-8. PubMed

54. Brown HE, Young A, Lega J, Andreadis TG, Schurich J, Comrie A. Projection of Climate Change Influences on U.S. West Nile Virus Vectors. Earth Interact 2015 Dec;19(18):18. DOI PubMed

55. Faust CL, McCallum HI, Bloomfield LS, Gottdenker NL, Gillespie TR, Torney CJ, Dobson AP, Plowright RK. Pathogen spillover during land conversion. Ecol Lett 2018 Apr;21(4):471-83. DOl PubMed

56. Iranpour M, Turell MJ, Lindsay LR. Potential for Canadian mosquitoes to transmit Rift Valley fever virus. J Am Mosq Control Assoc 2011 Dec;27(4):363-9. DOI PubMed 